\title{
JOHANN ANDREAS EISENBARETH, DOKTOR EISENBARETH
}

\author{
NOGUERA-PALAU JJ ${ }^{1}$
}

Famoso barbero-cirujano-oculista, también conocido como Doctor Milagro, nacido en Oberviechtach, Baviera, en 1663. Su padre y su cuñado fueron sus maestros durante diez años $y$, aunque nunca cursó estudios universitarios de medicina, el rey Guillermo de Prusia le otorgó el nombramiento de Oculista de la Real Corte, dato que consta en la lápida de su tumba en Minden, Hannover, lugar donde falleció en 1727.

Inventó una aguja para la intervención de cataratas por desplazamiento y con ella operó en varias ciudades alemanas adonde se hacía acompañar por un numeroso grupo de artistas, saltimbanquis, malabaristas, cantantes... quienes, mientras él trabajaba, distraían al público y disimulaban, probablemente, los gritos de dolor de sus clientes.

Algunos años después de su muerte, hacia 1800, se hizo famosa una larga canción popular: Ich bin der Doktor Eisenbarth.

En el sello de los correos alemanes vemos a Eisenbarth a punto de operar una catarata con el instrumento de su invención en la mano derecha; en la mitad inferior del sello, su cortejo. Este sello se emitió para conmemorar los 250 años de su muerte.

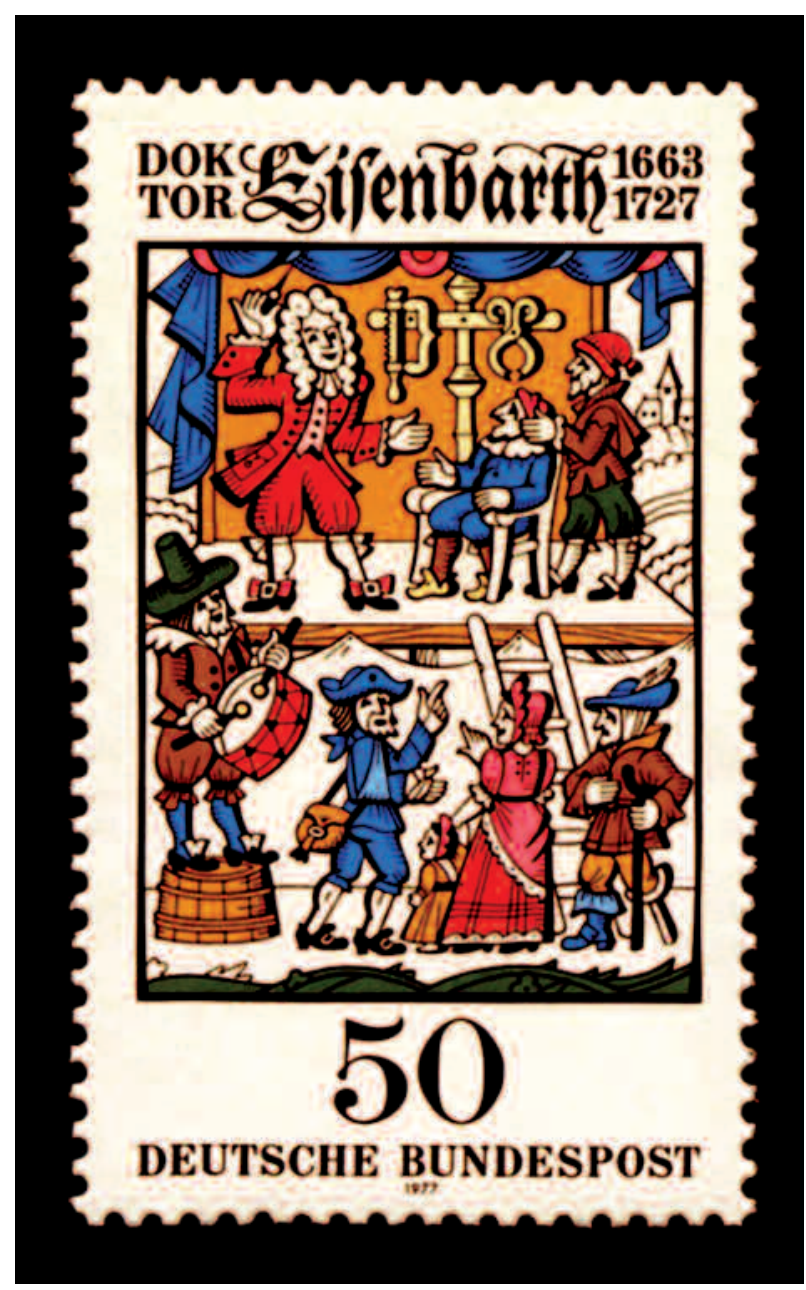

Alemania Federal, 1977 - Yvert 800.

\footnotetext{
1 Oftalmólogo. Pamplona.

E-mail: jnoguera72b@terra.es
} 